Krystyna Doktorowicz

Uniwersytet Śląski

e-mail: krystyna.doktorowicz@us.edu.pl

\title{
Google dla edukacji. Beneficja i zagrożenia dla oficjalnego systemu
}

\section{Abstract \\ Google for Education. Benefits and Threats to the Official System}

In 2017, the Google company was recognized as the most valuable brand in the world. It is primarily a technology corporation that aims to earn profits and become a leader in the global market of Internet products and services. In its strategy, Google also refers to the idea of a public mission, which is to consolidate the image of a company that serves the users by fulfilling their needs. As part of the mission, Google uses free educational applications designed to modernize and improve the education process. Google offers students and teachers tools to bridge the social differences and democratize the school. The educational practice in many countries points to the advantages and serious threats associated with the implementation of Google's educational applications. Violation of students' privacy, treating them as potential customers of the advertised products, or using student profiles to collect data - all this casts doubt on Google's intentions. It is also a challenge for traditional educational systems.

Keywords: education, Google, oppression, criticism

Słowa kluczowe: edukacja, Google, opresja, krytyka 
Google: wyszukiwarka na dobre czy na złe? - tak zatytułował rozdział o firmie Google Christian Fuchs w pracy Social Media: A Critical Introduction, poświęconej społecznym aspektom inwazji mediów społecznościowych ${ }^{1}$. W tytule tym ujawnia się dość powszechna wśród badaczy refleksja nad złożonością zjawiska, jakim jest Google, narzędzie współczesnej cywilizacji uznawane za źródło uniwersalnej wiedzy, ale także za przestrzeń opresji i manipulacji. Znaczenia wyszukiwarki i innych usług firmy Google nie sposób przecenić. Okres ich użytkowania pozwala nie tylko na opis zjawiska, jakim jest Google, ale także na analizę jakościową prowadzącą do konkluzji naukowych oraz rekomendacji dla użytkowników. Firma Google i jej wyszukiwarka, admirowana przez miliony użytkowników, podlega również poważnej krytyce w takich kwestiach jak unikanie opodatkowania, praktyki monopolistyczne, działania inwigilacyjne, naruszanie prywatności, pozycjonowanie treści czy odejście od neutralności wyszukiwania.

Badacze przedmiotu z Uniwersytetu Technologicznego w Grazu już w 2007 roku w raporcie poświęconym badaniom praktyk stosownych przez firmę Google zarówno wobec indywidualnych użytkowników, jak i globalnego rynku stwierdzali wręcz, że Google stanowi „zagrożenie dla ludzkości”. W przytaczanym raporcie autorzy zespołu kierowanego przez Hermanna Maurera wskazywali na zagrożenia wynikające z monopolistycznej pozycji wyszukiwarki, co czyni z Google globalnego gracza, który nigdy nie przegrywa. Gracz taki zagraża rynkom kapitałowym, konkurencyjności, prywatności, a przede wszystkim w wyniku dominacji swoich algorytmów przyczynia się do kreacji szczególnej wizji rzeczywistości. Badacze w konkluzjach wyrazili opinię, w której poddali krytyce wolnorynkowe reguły, jakim podlega Google, postulując konieczność kontroli czy regulacji sektora wyszukiwarek internetowych stanowiącego, ich zdaniem, dobro publiczne. Dekadę później, w 2017 roku, Komisja Europejska nałożyła na spółkę Google rekordową karę w wysokości 2,42 miliarda euro za stosowanie praktyk monopolistycznych, w tym nadużywanie dominującej pozycji poprzez faworyzowanie własnej porównywarki cenowej Google Shopping. W ostatniej dekadzie w znacznym stopniu wzrosła świadomość skutków strategii stosowanych przez Google - zarówno wśród użytkowników, jak i rządów, instytucji oraz organizacji odpowiedzialnych za rozwój społeczeństwa informacyjnego na rożnych poziomach uczestnictwa i zarządzania. Równocześnie jednak Google stanowi powszechny, o tyle codzienny, o ile niezbędny element funkcjonalny życia jednostek na całym świecie. Pomaga w poszukiwaniu, organizowaniu i przetwarzaniu informacji w każdej dziedzinie aktywności³. Google jest największą i najczęściej odwiedzaną wyszukiwarką. Firma Google została uznana w 2017 roku za najcenniejszą markę

${ }^{1}$ Ch. Fuchs, Social Media: A Critical Introduction, London 2017, s. 153.

${ }^{2}$ H. Maurer, Report on Dangers and Opportunities Posed by Large Search Engines, Particularly Google, Graz 2007.

${ }^{3}$ S. Vaidhyanathan, The Googlization of Everything (and Why We Should Worry), Berkeley 2011. 
na świecie. Założenie to musi towarzyszyć wszelkiej refleksji na temat pozytywnych i negatywnych skutków użytkowania jej produktów i usług. Zagrożenia i beneficja dla ekonomii, polityki, procesów społecznych, kultury czy edukacji, w które wikła jednostki i społeczeństwa Google, będą się dynamicznie pojawiać wraz z rozwojem nowych usług i kolejnych modeli biznesowych spółki.

Google, firma założona w 1998 roku przez Larry’ego Page’a i Sergeya Brina, od 2015 roku będąca spółką zależną korporacji Alphabet, zanotowała w ciągu ostatnich kilkunastu lat spektakularny sukces rynkowy i finansowy. W 2004 roku zajmowała 904. miejsce w rankingu największych korporacji pod względem wartości indeksu zysku, sprzedaży i wartości aktywów rynkowych, publikowanym przez Forbes Global 2000. W 2016 roku firma Google znalazła się już na 27. miejscu. Podstawowymi i najistotniejszymi usługami firmy są wyszukiwarka oraz serwisy reklamowe: AdWords i AdSense. Google oferuje także coraz większą liczbę usług wykraczających poza podstawową wyszukiwarkę. Należą do nich między innymi poczta elektroniczna Gmail, sieci społecznościowe Google+, komunikatory Hangouts, Dokumenty, Prezentacje i Arkusze, Tłumacz Google, Google Maps, Google Earth, a także YouTube czy oprogramowanie Google Chrome. W 2015 roku wszystkie serwisy Google miały ponad miliard aktywnych użytkowników miesięcznie ${ }^{4}$. W roku 2016 zysk Google wynosił 17 miliardów dolarów ${ }^{5}$.

Codzienność i niezbędność wyszukiwarki powoduje, że pojęcie „Google” stało się terminem obowiązującym we współczesnej kulturze z całym zbiorem znaczeń związanych z informacją i pozyskiwaniem informacji o rzeczywistości. Oxford English Dictionary definiuje pojęcie to google jako „wyszukiwanie informacji (o kimś lub o czymś) w Internecie przy użyciu wyszukiwarki Google"6. Słownik języka polskiego podaje: „googlować, potocznie: szukać informacji w internecie za pomocą wyszukiwarki Google”" Do języka potocznego weszły takie terminy jak: „zgooglować”, „zagooglować rzeczywistość”, „doktor Google” i wiele innych. Zbiór podobnych terminów, których źródłosłów tkwi w pojęciu „Google”, będzie się rozwijał. Nie ma ucieczki od użytkowania usług Google z wszystkimi tego konsekwencjami. Scott Galloway w swojej ostatniej pracy poświęconej funkcjonowaniu czterech największych i najistotniejszych dla globalnej zmiany kulturowej, ekonomicznej i społecznej firm technologicznych, czyli: Amazona, Apple, Facebooka i Google, zadaje pytania o przyczyny, dla których świat nie może się bez nich obejść ${ }^{8}$. Analizuje, w jaki sposób wywierają one wpływ na naszą świadomość, uwagę, lojalność, poczucie prywatności, co czynią z naszymi danymi osobowymi, jak sterują naszymi

\footnotetext{
${ }^{4}$ Tech Insider, https://www.facebook.com/techinsider/videos/426708157527546/ [odczyt: 1.02.2018].

${ }^{5}$ Ch. Fuchs, Social Media..., s. 154-155.

${ }^{6}$ https://en.oxforddictionaries.com [odczyt: 12.12.2017].

${ }^{7} \mathrm{https} / / / \mathrm{sjp}>$ googlować [odczyt: 12.12.2017].

${ }^{8}$ S. Galloway, The Four. The Hidden DNA of Amazon, Apple, Facebook and Google, London 2017.
} 
emocjami i pragnieniami. „Wielkiej Czwórce” ostatecznie wybacza się wszystkie grzechy. Robią to użytkownicy, biznes, giełda i rządy. Firmy te, twierdzi Galloway, unikają płacenia podatków, naruszają prywatność i niszczą miejsca pracy, aby zwiększyć zyski, ponieważ mogą to robić. Krytycyzm Gallowaya dotyczy zarówno firmy Google, jak i jej użytkowników, którzy widzą w usługach wyszukiwarki panaceum na wszystkie problemy od zdrowia, edukacji, przez prawo, po wiedzę naukową. Dla użytkowników Google wyszukiwarka i inne usługi są darmowe. Fakt ten daje im poczucie uczestnictwa we wcześniej niedostępnych przestrzeniach i stałego dostępu do zasobów kultury niematerialnej. Jest źródłem wolności i nieograniczonego wyboru. Przeciętny użytkownik wyszukiwarki Google nie rozważa zagrożeń makroekonomicznych w strategii firmy, lecz wykorzystuje przeglądarkę jako codzienne narzędzie pomagające mu w organizacji życia zawodowego i prywatnego. Korzysta z YouTubea czy Google Earth, doznając pozytywnych emocji i uzyskując praktyczne narzędzie pracy. Marka Google stała się nie tylko firmą komercyjną, zaspokajającą określone potrzeby użytkowników, ale także ideologią wyznawaną przez miliony, obejmującą wciąż nowe zasoby i terytoria. Google jest de facto monopolistą, prowadzi politykę globalną, tworzy swoiste projekty odróżniające firmę od konkurencji. Jak stwierdza Tim O’Reilly, Google jest nosicielem standardów dla Web 2.0 i mediów społecznościowych ${ }^{9}$. Nie sprzedaje się w kolejnych wersjach jak tradycyjne produkty software’owe. Google funkcjonuje jako dostarczyciel usługi bezustannie ulepszanej, otwiera niezależną od kontekstu przestrzeń reklamową. Google, jako firma, koncern, monopolista i dominujący gracz świadomy swojej pozycji kreatora zmiany i potentata ekonomicznego, przedstawia wiele swoich działań w kontekście swoistej misji publicznej. „Zmagając się” ze światowym sukcesem, admiracją użytkowników i krytyką analityków oraz konkurencji, Google określa swoją misję jako: „skatalogowanie światowych zasobów informacji i uczynienie ich powszechnie dostępnymi”"10. Stwierdzeniu temu towarzyszy hasło: Do the right things. Oświadczenie firmy z 2017 roku podkreśla znaczenie misji i wizji strategicznej Google, której podstawowym zadaniem ma być oferowanie użytkownikom innowacyjnych produktów i usług, łatwej w użyciu wyszukiwarki i pełnej dostępności do informacji ${ }^{11}$. Jak czytamy w dokumencie: wizja firmy polega na „udostępnianiu światu informacji za pomocą jednego kliknięcia”. Misja natomiast ma cztery elementy: „światową informację”, „organizację", „powszechną dostępność" i „użyteczność"12. Firma organizuje usługę udostępniania informacji za pomocą stworzonych dla niej tajnych algorytmów. Powszechna dostępność, koncepcja przypominająca europejski model uniwersalnego

9 T. O'Reilly, What is Web 2.0: Design Patterns and Business Models for Next Generation of Software, „Communication \& Strategies” 2007, no 1, https://www.papers.ssrn.com/sol3/cf_dev/AbsByAuth.cfm? [odczyt: 11.11.2017].

${ }^{10} \mathrm{http}: / /$ pl.wikipedia.org/wiki/Google [odczyt: 15.01.2018].

${ }^{11} \mathrm{http} / /$ www.panmore.com/google-vision-statement-mission-statement [odczyt: 15.01.2018].

12 Tamże. 
dostępu do usług informacyjnych i komunikacyjnych, ma zapewnić wszystkim w skali światowej demokratyczne i równe uczestnictwo. Firma uważa, że oferowany model przetwarzania i porządkowania informacji sprawia, iż wyniki wyszukiwania są efektywne i przydatne dla użytkowników. Google, poza swoją wyszukiwarką, podstawowym produktem, deklaruje rozwój nowych produktów i usług, co ma zapewnić użytkownikom satysfakcję, a firmie - zdolność do utrzymania dominującej pozycji biznesowej. Łączenie strategii biznesowych z misją ma uczynić z Google nowoczesną, progresywną, a jednocześnie przyjazną i demokratyczną korporację. Celom tym jest też podporządkowany system zatrudniania i pracy dla Google ${ }^{13}$. Tak przedstawiona ideowo wizja i misja firmy nie zmienia faktu, że jest to przede wszystkim korporacja akumulująca zysk, wykorzystująca dane osobiste i dane o aktywności użytkowników jako towar oferowany firmom reklamowym ${ }^{14}$. Jak pisze Christian Fuchs: Google „jest najlepszą maszyną do ekonomicznej inwigilacji i najlepszą maszyną wyzyskującą użytkowników" ${ }^{15}$. Google wciąż polemizuje z krytyką, a wiele usług oferowanych przez tę firmę, zdaniem jej przedstawicieli, wpisuje się w działalność misyjną, niemal altruistyczną, której celem jest zaspokajanie potrzeb użytkowników. Do takich należą usługi edukacyjne.

Jaime Casap, naczelny strateg i mentor firmy do spraw edukacji, promuje usługi Google, które mają zmienić proces edukacji, a także wyrównywać szanse społeczne młodzieży. W jednym $\mathrm{z}$ wywiadów mówi: „Technologia daje nam możliwość kwestionowania wszystkiego [...] możemy tworzyć doświadczenia edukacyjne, które są praktyczne, powtarzające i koncentrują się na ciągłym doskonaleniu”. Edukacja stała się kolejnym, wzbudzającym wiele kontrowersji polem działania koncernu. Szczególne wątpliwości budzi różnica między deklarowaną przez Google misją edukatora a faktyczną rolą firmy, która i w tej dziedzinie nie rezygnuje z pozycji monopolisty i agresywnego gracza rynkowego. Google wkracza w dziedzinę edukacji na wielu poziomach. Ideowo przedstawia się jako platforma służąca użytkownikom do poznawania świata. Dostarcza darmowych i łatwych w zastosowaniu narzędzi pozwalających na organizację procesu kształcenia i nauczania. Jest, zdaniem firmy, przyjazna, a z czasem stanie się niezbędna uczniom, nauczycielom i rodzicom. W 2013 roku firma Google utworzyła zespół do spraw polityki w dziedzinie usług i aplikacji edukacyjnych oraz opracowania i wdrożenia nowoczesnych produktów i usług. Udział Google w systemie edukacji publicznej, widoczny przede wszystkim w Stanach Zjednoczonych, ale także w Europie, w tym w Polsce, budzi tyle entuzjazmu, co krytyki i obaw związanych z zagrożeniem prywatności, bezpieczeństwem danych,

${ }_{13}$ Google Culture, http://www.google.com/intl/en/jobs/students/lifeatgoogle/culture [odczyt: 6.06 2016].

${ }^{14}$ M. Lee, Google Ads and the Blindspot Debate, „Media, Culture \& Society” 2011, no 33(3), s. 433-447.

${ }^{15}$ Ch. Fuchs, Social Media..., s. 160. 
wykluczeniem czy manipulacją potrzebami konsumenckimi uczniów. Google zmienia w znacznym stopniu filozofię edukacji szkolnej i uniwersyteckiej, koncentrując proces nauczania i kształcenia bardziej na technologii niż na uczniu czy studencie. Debata na temat metod edukacji, jakie proponuje Google, w aktywnej współpracy z nauczycielami, dotyczy modelu wykształcenia i rozwoju młodych użytkowników aplikacji edukacyjnych. Prowadzi do pytania: kogo kształcą współczesne wysoce technologiczne szkoły? Czy ich zadaniem jest wykształcenie wyspecjalizowanych pracowników, posiadających kwalifikacje technologiczne i wąskie umiejętności? Czy też podstawowym zadaniem szkoły jest wykształcenie świadomych, otwartych na nowe idee i kreatywnych obywateli? Rola Google w tej debacie jest o tyle istotna, że to właśnie ta firma technologiczna i jej usługi zaczynają dominować w szkołach w wielu regionach świata. Szczególnie od 2014 roku, kiedy została ogłoszona usługa Google Classroom.

Pozyskiwanie informacji i wiedzy przy użyciu wyszukiwarki w otwartym dostępie dla wszystkich prowadzi do zadawania bardziej ogólnych pytań badawczych o rzeczywistość przedstawioną w świecie wirtualnym, do którego najszersze wrota prowadzą przez Google. Jak już wspomniano, nie ma obecnie żadnego sposobu, aby to zmienić, i nie ma takiej potrzeby. Większość użytkowników Internetu odruchowo korzysta z wyszukiwarki również w celach edukacyjnych. Największą grupą użytkowników są ludzie młodzi, dla których treści pochodzące z sieci stanowią istotne źródło wiedzy zdobywanej poza szkołą. Pozycjonowanie treści w wyszukiwarce, które zapewnia aktualnie obowiązujący w Google algorytm, decyduje o tym, jakie informacje są pozyskiwane jako pierwsze. Pozycjonowanie informacji jest tajemnicą firmy. Stanowi przedmiot krytyki analityków i samych użytkowników. Przez długi czas uważano, ze Google jest nieformalnie związany z Wikipedią, której strony jako pierwsze pojawiały się w wyszukiwarce. Sytuacja ta zmieniła się w 2015 roku, kiedy to Wikipedia zanotowała znaczący spadek odwiedzin, najprawdopodobniej, jak twierdzi jej współzałożyciel Jimmy Wales, na skutek zmiany algorytmu Google ${ }^{16}$. Niewątpliwie Google przyczynia się do kreowania określonego obrazu świata, na który wpływ mają algorytmy i modele biznesowe firmy. Korzystanie z dominującej przeglądarki prowadzi do akceptacji sformatowanych źródeł informacji i tolerancji dla zespołu zjawisk zwanych postprawdą. Niektórzy badacze określają ten proces mianem „zagooglowania świata”. Jak masowe korzystanie z przeglądarki Google odbije się na poziomie znajomości podstawowych procesów społecznych, ekonomicznych czy kulturowych wśród przeciętnych użytkowników obecnych młodych generacji, ujawni się w następnych dekadach i będzie miało znaczący wpływ na przyszłe społeczeństwa. Rozważania te prowadzą do pytań o zagrożenia i nieuniknione niekorzystne zmiany wywoływane przez dynamiczny rozwój i udomowienie

${ }^{16} \mathrm{https} / /$ www.searchengineland.com/wikipedia-comfirms-they-are-steadily-losing-google-trafic-228237 [odczyt: 15.01.2018]. 
technologii. Zmiany te są bardzo trudne do antycypacji ze względu na ich szybkość, zmienność pozycji użytkowników technologii i mediów oraz wszechobecną grę rynkową największych korporacji technologicznych. Niewątpliwie już dziś można poddać analizie politykę firmy Google w zakresie jej wpływu na system edukacji publicznej, określić jej wartość, zalety oraz działania niekorzystne i im przeciwdziałać. Analiza wypowiedzi na blogach dla nauczycieli w Polsce wskazuje na duże zainteresowanie i pozytywny odbiór narzędzi Google przez tę grupę zawodową ${ }^{17}$.

Usługi Google dla szkół i uczelni przedstawiane są jako: bezpieczne, dostępne, łatwe w obsłudze i niezawodne. Polecane są nauczycielom, uczniom i rodzicom, są bezpłatne, nowoczesne i, jak twierdzi Google, niezbędne w procesie nauczania w XXI wieku. Liczne strony internetowe dostarczają informacji dla administratorów, o zakresie usług, procedurach korzystania $\mathrm{z}$ aplikacji, uzyskiwaniu zgody na używanie narzędzi czy o polityce prywatności ${ }^{18}$. Google Apps for Education (Google Apps dla Szkół i Uczelni) stanowiły pierwszy zaproponowany w 2006 roku przez firmę Google zestaw narzędzi internetowych dla szkół ${ }^{19}$. Podstawę tego pakietu tworzyły: Gmail, Kalendarz Google, Dokumenty i Witryny, a także narzędzia dodatkowe w postaci: usługi archiwizacyjnej poczty i czatu (Vault), usługi zakupu i wdrożenia aplikacji pozwalających na integrację z innymi narzędziami Google (Apps Marketplace), aplikacji tworzącej grupy dyskusyjne (Moderator Google), filmów edukacyjnych, (YouTube for Education), tłumacza (Google Translate) i blogów. Google Apps for Education były zestawem usług darmowych, pozwalających na zdalne zarządzanie procesem dydaktycznym. Korzystanie z usług edukacyjnych firmy Google miało na celu uczenie pracy zespołowej. Kolejną wersją pakietu usług edukacyjnych dla szkół i uczelni jest G Suite for Education (G Suite dla Szkół i Uczelni). Jest to dynamicznie rozwijający się zestaw usług obejmujący: Gmail, Google Dysk, Google Classroom, Google Chrome, Kontakty, Formularze, Dokumenty, Prezentacje, Kalendarz, Witryny, Grupy dyskusyjne, Talk/Hangouts (komunikator tekstu, głosu i wideo), Vault. W 2016 roku pojawiły się aktualizacje określane przez Google jako: bardziej inteligentne dokumenty, bardziej inteligentne prezentacje, inteligentniejsze planowani $^{20}$. Do usług dodatkowych w zestawie należy zaliczyć miedzy innymi YouTube, Google Maps czy Blogger. Usługi dodatkowe mogą być dostępne i używane na kontach G Suite for Education do celów edukacyjnych, jeżeli zezwoli na to administrator szkolnej domeny. Ponadto do narzędzi edukacyjnych zaliczane są także: Analitics - profesjonalny zestaw narzędzi do analizy serwisów WWW,

${ }^{17}$ https://www.superbelfrzy.edu.pl/pomyslodajnia/narzędzia-google-w-edukacji [odczyt: 15.01. 2018].

${ }^{18} \mathrm{https} / /$ www.google.com.edu-home-googlefor education [odczyt: 10.01.2018].

${ }^{19}$ https://www.edulider.pl/edukacja [odczyt: 16.01.2018].

${ }^{20} \mathrm{~J}$. Rochelle, Director of Product Management, Google for Education. Introducing G Suite for Education, 4.10.2016, https://www.blog.google/topics/education/introducing-g-suite-education/ [odczyt: 24.01.2018]. 
Google Translate, Google Earth, Google Mars, Google Moon, Google Art Project zawierający dostęp do muzeów i zasobów sztuki z całego świata, Picasa - bezpłatny pakiet do obsługi grafiki, moderator Google, Sketch up - oprogramowanie do modelowania 3D oraz do nauki rysowania przestrzennego. Departament zajmujący się produktami edukacyjnymi zbiera opinie użytkowników, edukatorów, uczniów, administratorów i rodziców w celu pozyskania informacji o potrzebach edukacyjnych. Dla najmłodszych użytkowników przeznaczony jest zestaw usług o nazwie Google CS, którego zadaniem jest wdrożenie systemu informatycznego dla niższych klas szkoły podstawowej ${ }^{21}$.

W 2014 roku firma Google ogłosiła swoje flagowe zintegrowane narzędzie, jakim jest Google Classroom. Jest ono częścią G Suite for Education, integruje wszystkie wcześniej wprowadzone narzędzia w jeden pakiet i pozwala na prowadzenie procesu nauczania i komunikowania między nauczycielami i uczniami oraz między uczniami całkowicie on-line ${ }^{22}$. W 2017 roku Google udostępnił aplikację wszystkim użytkownikom bez wymogu posiadania konta G Suite for Education, jedynie z kontem osobistym Google. Aplikacja jest darmowa, daje możliwość tworzenia wirtualnych klas, w których proces informacji, komunikacji, pobierania prac i ich oceny odbywa się elektronicznie. Zawiera usługi podstawowe i dodatkowe. Z systemem zintegrowany jest Kalendarz Google, pozwalający na szybkie przekazywanie on-line wszelkich informacji organizacyjnych, harmonogramów, terminów zajęć szkolnych i pozalekcyjnych, zmian czasowych i obiektowych czy informacji o rozdzielaniu zadań wśród uczniów. Każda klasa pracująca w aplikacji Google Classroom tworzy oddzielne foldery na Dysku Google, z którego uczeń może przesłać prace nauczycielowi. Google Classroom oferuje wiele rożnych wzorców oceniania. Nauczyciele w każdej chwili mają możliwość dołączania nowych plików do zadań, które uczniowie mogą przeglądać, edytować i tworzyć własne kopie. Nauczyciele zdalnie monitorują postępy uczniów, wprowadzają uwagi i komentarze, mogą się kontaktować z rodzicami. Aplikacja pozwala na tworzenie grup dyskusyjnych, dwukierunkową komunikację ucznia z nauczycielem, dołączenie do ogłoszeń i postów treści pochodzących z innych produktów Google. Uczniowie i nauczyciele funkcjonują w sieci społecznościowej, która pozwala na oszczędność czasu, mobilizację uczniów i archiwizację kursów. Zaletą aplikacji Google Classroom jest zintegrowany z nią bogaty zestaw aplikacji dodatkowych, w tym rzadko używanych, o znakomitych walorach edukacyjnych, jak: Google Cultural Institute, Art Project, World Wonders Project do poznawania niezwykłych miejsc na Ziemi, specjalnie przystosowane do Google Classroom Google Maps i Street View, Google Maps Engine do własnego tworzenia map czy Sketch Up do prostych projektów w 3D ${ }^{23}$. Poprzez Google Classroom dostępny jest

\footnotetext{
${ }^{21}$ https://www.csfirst.withgoogle.com [odczyt: 16.01.2018]

${ }^{22} \mathrm{https} / /$ www.edu.google.com/Intl/pl/products/productivity-tools/classroom [odczyt: 17.01.2018].

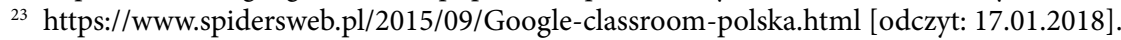


także YouTube for Education oraz Google Scholar. Google Scholar skierowany jest przede wszystkim do środowiska akademickiego. Jest ogólnodostępną wyszukiwarką indeksującą literaturę naukową z całego świata. Zapewnia dostęp do większości recenzowanych czasopism naukowych, książek i artykułów, prac dyplomowych, streszczeń, raportów naukowych, prac technicznych, opisów patentów i opinii sądowych. Narzędzia Google Classroom nie zastąpią wysoce specjalistycznych aplikacji dla nauk technicznych, ścisłych i zaawansowanej translatoryki. Niemniej mają szerokie zastosowanie w szkolnictwie podstawowym, średnim i akademickim. Aplikacja ta uwalnia uczestników procesu nauczania od papierowych dokumentów. W Polsce usługi Google Classroom dostępne są od 2015 roku, a od 2017, podobnie jak na świecie, dostępne są bez konieczności posiadania konta G Suite for Education. W sieci funkcjonują instrukcje dostępu i funkcji w języku polskim. Google umieścił na YouTube poradniki dla nauczycieli i uczniów wskazujące, jak korzystać z aplikacji. Funkcjonują portale opinii, grupy dyskusyjne nauczycieli i blogi. Przeważają pozytywne i entuzjastyczne opinie. Poradniki przygotowywane są przez samych nauczycieli i publikowane w sieci. Coraz więcej szkół w Polsce przystępuje do programu. Administratorzy Google Suite for Education i Google Classroom decydują, jakie usługi Google będą dostępne dla użytkowników. W przypadku uczniów nieletnich konieczna jest zgoda opiekunów. Po uzyskaniu takiej zgody użytkownicy bez ograniczeń mogą korzystać z usług dodatkowych. Google Classroom zyskał przewagę nad podobnymi aplikacjami Microsoftu czy Apple, oferując program darmowy oraz prowadząc ofensywną politykę marketingową. Podstawowe korzyści, jak podaje Google na swoich stronach, to:

łatwa konfiguracja - nauczyciele mogą tworzyć zajęcia i zapraszać na nie uczniów współprowadzących. W strumieniu zajęć mogą oni udostępniać informacje-zadania, ogłoszenia i pytania; oszczędność czasu i papieru; lepsza organizacja - uczniowie mogą znaleźć zadania na stronie Do Zrobienia, w strumieniu zajęć i w kalendarzu zajęć. Materiały automatycznie zapisywane są w folderach na Dysku Google; sprawniejsza komunikacja i przekazywanie uwag - nauczyciele mogą tworzyć zadania, wysyłać ogłoszenia i natychmiast rozpocząć klasowe dyskusje. Uczniowie mogą dzielić się materiałami oraz komunikować się w strumieniu zajęć lub przez e-maile. Nauczyciele mogą bezpośrednio przekazywać swoje uwagi w czasie rzeczywistym oraz wystawiać oceny; współpraca z innymi aplikacjami; przystępność i bezpieczeństwo usługa Classroom jest bezpłatna. Classroom nie zawiera reklam, a materiały nauczycieli i dane uczniów nie są wykorzystywane do celów reklamowych ${ }^{24}$.

Podobne funkcje oferują w swoich aplikacjach edukacyjnych Microsoft i Apple, niemniej Google zyskuje przewagę (głównie w Stanach Zjednoczonych), także ze

${ }^{24}$ https://www.support.google.com/edu/classroom/answer/6020279?hl=pl\&ref_topic+71755444 [odczyt: 18.01.2018]. 
względu na opinie nauczycieli i rodziców mających łatwy dostęp do wyników nauczania uczniów ${ }^{25}$. Zestawienia korzyści płynących z zastosowania aplikacji Microsoftu, Google i Apple wskazują na przewagę funkcjonalną Google Classroom. Ofensywa marketingowa i reklamowa Google w zakresie edukacji oraz system informacji, promocji i szkoleń sprawia, że firma w latach 2015-2017 osiągnęła dominującą pozycję w szkołach amerykańskich ${ }^{26}$. W Stanach Zjednoczonych edukatorzy mówią o zjawisku „zgooglenia” szkoły. Ponad 15 milionów z 30 milionów amerykańskich uczniów korzysta z aplikacji edukacyjnych Google ${ }^{27}$. Zastosowanie Google Classroom w szkołach amerykańskich ze względu na jego skalę jest stosunkowo dobrze udokumentowane. Szkoły, edukatorzy i administracja szkolna prowadzą debatę zarówno na temat korzyści zastosowań aplikacji edukacyjnych, zmiany filozofii nauczania i kształcenia, jak i zagrożeń płynących z dominacji narzędzi elektronicznych w szkołach. Szerokie zastosowanie aplikacji Google w szkołach prowadzi do podobnych refleksji i krytyki, z jaką spotyka się firma Google w kontekście funkcjonowania wyszukiwarki. Dotyczy to przede wszystkim polityki prywatności, ochrony danych młodych użytkowników, pozycjonowania treści i reklam oraz potencjalnego wikłania uczniów w tworzenie grup lojalnych konsumentów. Debata nad zastosowaniem Google Classroom wyszła poza wymianę poglądów na temat korzyści jej użytkowania. Dotyczy także ideologii i modeli kształcenia w szkołach podstawowych i średnich. Obecnie można już dokonać analizy i na jej podstawie stwierdzić, że zastosowanie narzędzi takich jak Google Classroom wpływa na jakość i istotę wykształcenia ucznia oraz jego zdolności do dalszego nabywania wiedzy, umiejętności i zdolności do zmiany. Niewątpliwie uczniowie rozwijają swoje umiejętności w zakresie pracy zespołowej, korzystania $\mathrm{z}$ wysokich technologii w procesie uczenia i pracy, są bardziej zdyscyplinowani i mobilni. Technologia pozwala im na przenikanie się czasu nauki i czasu wolnego. Firma Google motywuje uczniów i nauczycieli do stosowania swojej aplikacji, utrzymując, że wpłynie to na perspektywę ich kariery zawodowej i będzie sprzyjało konkurencyjności.

Google jest jednak przede wszystkim korporacją, której cel to gromadzenie zysku. Prowadzi grę rynkową, w której stosuje idee misji publicznej. W ramach misji wdraża darmowe aplikacje edukacyjne, które deklaratywnie powinny unowocześniać i usprawniać proces edukacji. W myśl polityki Google narzędzia edukacyjne mają niwelować różnice społeczne i demokratyzować szkolnictwo przez dostarczanie wszystkim uczniom-użytkownikom tych samych narzędzi, a tym samym tych samych możliwości. Praktyka szkolna w USA ujawniła już różnice systemów

${ }^{25}$ https://www.edsurge.com./news/2017-02-22-battle-of-the classroom-apple-google-microsoft [odczyt: 18.01.2018].

${ }^{26}$ N. Singer, How Google Took Over Classroom, „The New York Times” 2017, May 13.

${ }^{27}$ https://www.suport.google.com/edu/Classroom/answer/602079?hl=pl\&ref_topic=7175444 [odczyt: 18.01.2018]. 
wartości ujawniające się pomiędzy polityką władz oświatowych a polityką biznesu Google. Podstawą dyskusji jest podejście normatywne i rzeczywiste firmy Google do polityki prywatności i wykorzystywania danych osobowych uczniów. Istnieje bowiem niebezpieczeństwo traktowania uczniów jako potencjalnych klientów w przyszłości, nawykłych w okresie szkolnym do korzystania z aplikacji określonych firm. Przedmiotem zainteresowania edukatorów i rodziców jest również wykorzystanie danych uczniów w celu tworzenia ich profili i używanie w procesie pozycjonowania reklam w ich dorosłym życiu. Google, w przeciwieństwie do innych firm technologicznych, czerpie większość swoich zysków z reklam w Internecie. Stąd też specjaliści z Google stosują wyrafinowane algorytmy pozwalające na gromadzenie i wykorzystanie danych użytkowników w celach komercyjnych. Google, świadomy tej krytyki, publikuje ogólne zasady polityki prywatności. W dokumentach polityki prywatności w kontekście edukacji w Google czytamy: „Dane osobowe użytkownika są wykorzystywane wyłącznie w celu zapewnienia dostępu do podstawowych usług. Google nie wyświetla reklam w usługach podstawowych i nie wykorzystuje zebranych danych do celów promocyjnych"28. W zakresie usług dodatkowych, bez których narzędzie Google Classroom nie funkcjonuje efektywnie, zasady polityki prywatności nie są już tak jednoznaczne. Jak podaje Google: „Dzięki otrzymanym danym możemy wspierać, chronić, ulepszać istniejące usługi i opracowywać nowe, a także zapewnić bezpieczeństwo Google i naszym użytkownikom. Te dane są potrzebne w celu dokładniejszego personalizowania treści, w tym w celu zwiększenia trafności wyników wyszukiwania" ${ }^{29}$. Usługi dodatkowe w aplikacji G Suite for Education, w tym Google Classroom, nie ograniczają wyświetlania reklam. Jak zapewnia firma, Google nie wykorzystuje żadnych danych osobowych ani w usługach podstawowych, ani w usługach dodatkowych do kierowania reklam. Firma Google deklaruje, że nie udostępnia danych osobowych użytkowników usług podstawowych i dodatkowych podmiotom trzecim, z wyjątkiem takich przypadków, kiedy uzyskano zgodę użytkownika, a jeżeli wymaga tego zarządzanie usługą, wykonywane jest zewnętrzne przetwarzanie danych (dotyczy to oddziałów Google oraz innych zaufanych firm i osób prywatnych w celu przetwarzania danych w imieniu Google), albo jeżeli wymaga tego prawo. Google oferuje także szkołom i rodzicom narzędzia kontroli, ustawienia dostępu i usuwania treści. Szkoły i uczelnie, podpisując umowy na korzystanie z G Suite for Education, przyjmują warunki korzystania z usług Google i politykę prywatności. Google deklaruje przejrzystość polityki prywatności w zakresie ochrony nieletnich $w$ relacjach pozaszkolnych. Oferuje rodzicom aplikację Family Link, która pozwala na kontrole rodzicielską na kontach dzieci poniżej

${ }^{28}$ https://www.gsuite.google.com/terms/education-privacy.html [odczyt: 15.01.2018].

${ }^{29} \mathrm{https} / /$ www.familie.google.com/familylink/privacy/child-policy/?utm_source=google -privacy-policy\&hl=pl [odczyt: 18.01.2018]. 
13. roku życia, niemogących samodzielnie zarządzać kontami ${ }^{30}$. Oczywiście polityka ta w ostateczności pozwala na pozyskiwanie kolejnych użytkowników Google.

Warunki polityki prywatności, choć bardzo rozbudowane, budzą zastrzeżenia, gdyż Google odmawia podania szczegółowych informacji na temat gromadzonych danych uczniów. Zawierają także wiele ogólnie sprecyzowanych wyjątków. Google nie ujawnia swojego modelu biznesowego w przypadku aplikacji edukacyjnych. Niejasna pozostaje sytuacja, kiedy uczniowie logują się do Dokumentów Google nie ze swoich komputerów. Google wprawdzie zapewnia, że działa zgodnie z prawem amerykańskim i unijnym, niemniej długo negocjował podpisanie w USA umów zgodnych z federalną ustawą o prawach dziecka w zakresie edukacji i prywatności. Podkreśla natomiast znaczenie i gwarancje własnej polityki prywatności. Jak pokazuje przypadek szkół w Chicago, opisywany szczegółowo w marcu 2017 roku przez „The New York Times”, Google ekspansywnie oferował swoje usługi bezpośrednio szkołom i nauczycielom z pominięciem władz oświatowych. Chicago zostało wybrane przez firmę w 2014 roku na swoisty poligon doświadczalny wprowadzania Google Classroom do szkól, przy jednoczesnym rugowaniu aplikacji Microsoftu. Strategia marketingowa Google okazała się w Stanach Zjednoczonych bardzo skuteczna; początkowo w szkolnictwie wyższym, a następnie w podstawowym i średnim. Działania polegały na przekonywaniu nauczycieli przez emisariuszy Google. Oni z kolei mieli wpłynąć na władze oświatowe i przedstawicieli innych szkół. Nie bez znaczenia był czynnik ekonomiczny. Dzięki zastosowaniu aplikacji Google Classroom szkoły w Chicago oszczędzają 1,6 miliona dolarów rocznie na kosztach związanych z e-mailami.

Google przedstawia się jako potęga edukacyjna i prowadzi intensywną działalność w Internecie oraz przez bezpośrednie spotkania, konferencje i szkolenia. Utworzył dziesiątki społeczności internetowych zwanych Grupami Google Educator, w ramach których nauczyciele wymieniają się doświadczeniami i poglądami na temat aplikacji Google, jednocześnie promując Google Classroom ${ }^{31}$. Dla użytkowników Google Classroom powołane zostało, działające w wielu krajach, biuro Help Center. Firma publikuje studia przypadków i prowadzi Product Forum dla Google Classroom. Do istotnych elementów strategii marketingowej należy polityka motywowania nauczycieli i uczniów do przekazywania informacji na temat zalet Google Classroom w mediach społecznościowych. Google jest inicjatorem i sponsorem konferencji edukacyjnych i sympozjów dla nauczycieli oraz władz i urzędników oświatowych. W 2014 roku Google rozpoczął akcję promocyjną od ogłoszenia darmowego testowania aplikacji Classroom. Na ogłoszenie odpowiedziało ponad 100 tysięcy nauczycieli z całego świata, co przyczyniło się do zwiększenia

${ }^{30} \mathrm{https} / /$ www.familie.google.com/familylink/privacy/child-policy/?utm_source=google-privacy-policy\&hl=pl [odczyt: 18.01.2018].

${ }^{31}$ https: //www.google.com/landing/geg/ [odczyt: 15.01.2018]. 
popytu na aplikację. Wielu krytyków firmy Google zarzuca jej wykorzystywanie nauczycieli i uczniów jako darmowych zasobów. Opinie i testy pozwalają firmie na udoskonalanie Google Classroom i tym samym zwiększanie oferty oraz pozyskiwanie nowych klientów. Kolejnym zabiegiem marketingowym było wprowadzenie do szkół tanich laptopów o nazwie „chromebook”, które działają w systemie Google Chrome. Urządzenia te są tanie, niewielkie i lekkie, a większość zawartych na nich aplikacji i danych znajduje się w chmurze, nie w samym komputerze. Stąd też stały się dominującymi urządzeniami na rynku edukacyjnym. Aplikacja Google Classroom zadecydowała o rozwoju sprzedaży chromebooków. W Stanach Zjednoczonych w 2016 roku chromebooki stanowily 58\% z 2,6 miliona urządzeń mobilnych kupowanych przez szkoły ${ }^{32}$. Spowodowało to jednoczesny gwałtowny spadek sprzedaży tabletów i laptopów firmy Apple. Google nie zarabia bezpośrednio na chromebookach, gdyż ich producentami są miedzy innymi Samsung, Acer, Dell czy Toshiba. Pobiera natomiast opłaty od szkół za ich użytkowanie. Zastosowanie tych laptopów w zestawieniu z aplikacją Google Classroom wywołało wiele kontrowersji w kontekście naruszania prawa do prywatności uczniów oraz ochrony danych osobowych. Electronic Frontier Foundation - międzynarodowa organizacja działająca na rzecz promowania swobód i praw obywatelskich w Internecie - oskarżyła w 2015 roku firmę Google o naruszanie prywatności uczniów w wyniku domyślnego włączania funkcji synchronizacji w Google Chrome, umożliwiającej przeglądanie i przechowywanie danych uczniów oraz wykorzystywanie ich w celach pozaedukacyjnych ${ }^{33}$. Krytyka, która spotyka firmę Google w zakresie usług edukacyjnych, dotyczy włączenia ich w strategię biznesową i przypisywanie aplikacjom edukacyjnym znaczeń handlowych. Nie powstrzyma to jednak korporacji przed tworzeniem nowych udoskonalonych produktów i usług przynoszących satysfakcję użytkownikom i zyski firmie. Beneficja i zagrożenia będą towarzyszyć temu procesowi.

\section{Bibliografia}

Fuchs Ch., Social Media: A Critical Introduction, London 2017.

Galloway S., The Four. The Hidden DNA of Amazon, Apple, Facebook and Google, London 2017. Lee M., Google Ads and the Blindspot Debate, „Media, Culture \& Society” 2011, no 33(3).

Maurer H., Report on Dangers and Opportunities Posed by Large Search Engines, Particularly Google, Graz 2007.

Singer N., How Google Took Over Classroom, „The New York Times” 2017, May 13.

Vaidhyanathan S., The Googlization of Everything (and Why We Should Worry), Berkeley 2011.

${ }^{32}$ https://www.en.wikipedia.org/Wiki/Chromebook [odczyt: 15.01.2018].

${ }^{33}$ https://www.eff.org/tags/google [odczyt: 18.01.2018]. 


\section{Netografia}

O'Reilly T., What is Web 2.0: Design Patterns and Business Models for Next Generation of Software, „Communication \& Strategies” 2007, no 1, https://www.papers.ssrn.com/sol3/cf_dev/ AbsByAuth.cfm? [odczyt: 11.11.2017].

Rochelle J., Director of Product Management, Google for Education. Introducing G Suite for Education, 4.10.2016, https://www.blog.google/topics/education/introducing-g-suite-education/ [odczyt: 24.01.2018].

Tech Insider, 23.10.2015, https://www.facebook.com/techinsider/videos/426708157527546/ [odczyt: 1.02.2018].

www.csfirst.withgoogle.com [odczyt: 16.01.2018].

www.edsurge.com [odczyt: 18.01.2018].

www.edu.google.com [odczyt: 17.01.2018].

www.edulider.pl [odczyt: 16.01.2018].

www.edunews.pl/ [odczyt: 1.02.2018].

www.eff.org [odczyt: 18.01.2018].

www.en.wikipedia.org [odczyt: 15.01.2018].

www.en.oxforddictionaries.com [odczyt: 12.12.2017].

www.familie.google.com [odczyt: 18.01.2018].

www.google.com [odczyt: 6.06.2016] [odczyt: 10.01.2018] [odczyt: 15.01.2018].

www.gsuite.google.com [odczyt: 15.01.2018].

www.panmore.com [odczyt: 15.01.2018].

www.searchengineland.com [odczyt: 15.01.2018].

www.sjp>googlować [odczyt: 12.12.2017].

www.spidersweb.pl [odczyt: 17.01.2018].

www.superbelfrzy.edu.pl [odczyt: 15.01.2018].

www.support.google.com [odczyt: 18.01.2018].

www.qualityandinnovation.com [odczyt: 1.02.2018]. 